\title{
Pollen Spectrum of Honey from the Bee Melipona subnitida Ducke (1910) in Restinga in Maranhão State
}

\author{
Maira Rodrigues Diniz ${ }^{1}$ (D) \\ Albeane Guimarães Silva ${ }^{1}$ (D) \\ Léa Maria Medeiros Carreira² \\ Eduardo Bezerra de Almeida Jr., ${ }^{1,3}$ (D) \\ Márcia Maria Corrêa Rêgo ${ }^{1,3}$
}

\begin{abstract}
The study aimed to analyze the honey of Melipona subnitida to identify the plants visited by these bees in colonies installed in a restinga vegetation in Maranhão state. Honey was collected monthly from July/2017 to June/2018. The honey samples were submitted to the acetolysis method and the pollen grains were analyzed qualitatively and quantitatively. The pollen analysis of honey resulted in 54 pollen types and 26 families. The largest pollen variety was registered in Fabaceae. Quantitative analyzes of pollen grains in honey samples revealed that three were monofloral, in July/2017 with Avicennia germinans honey and December/2017 and January/2018 with Copaifera martii honey. In the other months, the heterofloral honeys. Melipona subnitida proved to be general in food gathering. Knowing the flora used by M. subnita contributes to the meliponiculturists to improve the handling of the colonies, the increase and quality in the production of honey.
\end{abstract}

Keywords: Delta do Parnaíba, Dunes, meliponiculture, mangrove, pollen spectrum.

\section{INTRODUCTION AND OBJECTIVES}

Native stingless bees comprise the species belonging to the tribe Meliponini out of the family Apidae, which include the representatives of the genus Melipona (Michener, 2007). This genus comprises the largest number of species in Brazil, being highlighted for its great richness in biodiversity (Camargo \& Pedro, 2007).

Among the bees of the genus Melipona, the specie Melipona subnitida Ducke (1910), popularly known as jandaíra, is one of the most suitable species for breeding in semiarid environments (Cruz et al., 2004), due to its adaptations to the stressful conditions of this environment (Maia-Silva et al., 2015). Although the species occurs commonly in caatinga areas, Rêgo \& Albuquerque (2006) found it in Maranhão in a restinga area, after 14 years of not appearing in works with apifaunistic surveys. More recently, it has been colonizing other environments such as mangroves, thus expanding the spectrum of plants used in its foraging (Rêgo et al., 2017).

Stingless bees are extremely connected to their environment by its floral resources (Villas-Bôas, 2012). Bees search for essential nutrients for their development and maintenance of broods and colonies. Therefore they collect nectar, pollen, and water.

During the search for these resources, when collecting nectar, forages also involuntarily collect pollen, and this pollen appears in honey. The pollen serves as an indicator

\footnotetext{
${ }^{1}$ Universidade Federal do Maranhão, Programa de Pós-Graduação em Biodiversidade e Biotecnologia da Rede BIONORTE, São Luís, MA, Brasil

${ }^{2}$ Museu Paraense Emilio Goeldi, Belém, PA, Brasil

${ }^{3}$ Universidade Federal do Maranhão, Departamento de Biologia, Programa de Pós-Graduação em Biodiversidade e Conservação, São Luís, MA, Brasil
} 
of botanical and geographical origin of the honey (Barth, 1989). Furthermore is possible to evaluate those data of the pollen spectra in the honey samples and identify possible preferences (Luz \& Barth 2012; Pinto et al. 2014; Costa et al. 2017; Caravela et al. 2019).

According to Rêgo et al. (2017), identifying plant species used by bees as food resources is extremely important to assess their potential food sources for maintaining their colonies and brood production, and to assist honey farmers to choose plant species grown in their areas. Thus, the objective of this work was to identify the plants visited by Melipona subnitida using/examining pollen profile present in honey samples from colonies housed in "caboclas" boxes (Venturieri et al., 2003) in the Restinga area. This study will contribute information that will increase the knowledge about the honey plants of Maranhão.

\section{MATERIALS AND METHODS}

\subsection{Study area}

Ilha Grande do Paulino is located in the municipality of Tutóia and falls within the Delta do Parnaíba Environmental Protection Area ( $\left.2^{\circ} 43^{\prime} 58.2^{\prime \prime} \mathrm{S} / 42^{\circ} 11^{\prime} 23.4^{\prime \prime} \mathrm{W}\right)$ (Figure 1 and 2 ). The island is one of the largest in the Parnaiba Delta with approximately 4,302 hectares. The climate is classified as Aw (tropical with dry winter season) according to the classification Köppen \& Geiger (1928). The area is marked by two seasons: the dry season from July to December and the rainy season from January to June (Oliveira \& Frota, 2011). During the rainy season the precipitation is intense. The natural environment is made up of different types of soil, with sandy or clayey soils, the latter almost always in areas that are seasonally flooded (Prompt, 2010).

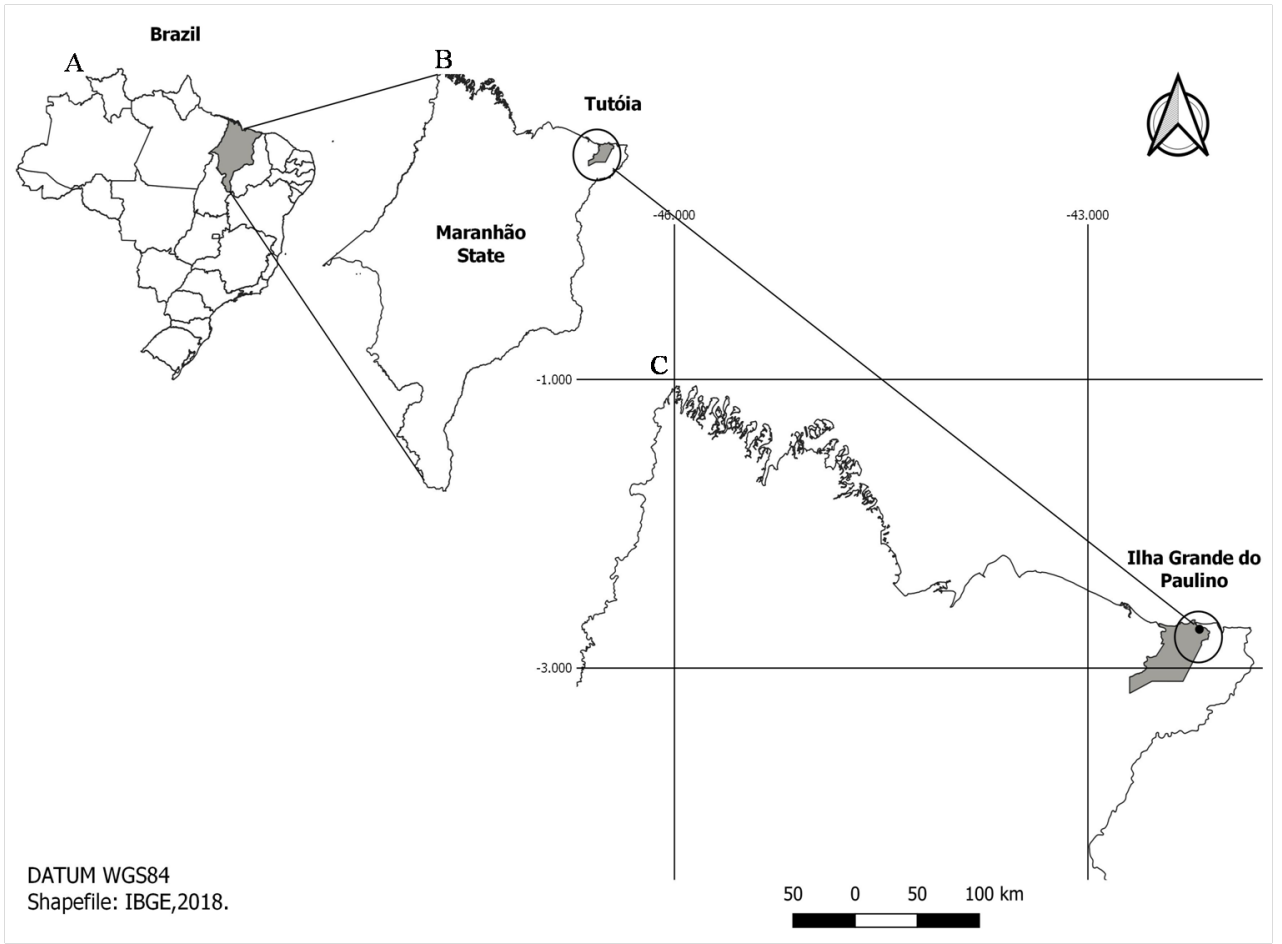

Figure 1. Location map of the study area. A- Map of Brazil with emphasis on the Maranhão state; B- Map of the state of Maranhão, showing the location of the study area in relation to the state; $\mathbf{C}$ - Magnification of the map showing Ilha Grande do Paulino, municipality of Tutóia. 

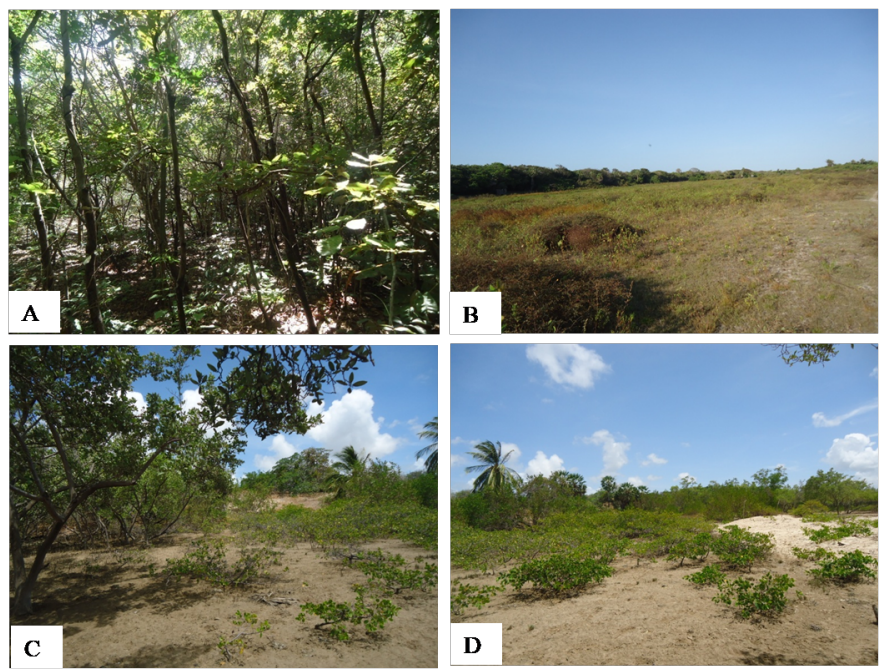

Figure 2. Partial view of restinga vegetation (A and $B$ ) and mangrove (C and D), Ilha Grande do Paulino, municipality of Tutóia, Maranhão state.

\subsection{Collection of honey and pollen analysis}

In total, 48 samples of honey were obtained from colonies of Melipona subnitida in the period from July/2017 to June/2018. The bee colonies were, housed in four "caboclas" boxes (Venturieri et al., 2003), in the same period in which the botanical material was collected. A total of $10 \mathrm{~mL}$ of honey was obtained from each colony with the aid of a syringe, being placed in a Falcon tube.

At the Bee Studies Laboratory (LEA), all honey samples were prepared according to the standardized method of Louveaux et al. (1970). This method consists of dissolving $10 \mathrm{~mL}$ of honey in $20 \mathrm{~mL}$ of distilled water and centrifuging at $2000 \mathrm{rpm}$ for 5 minutes. The supernatant was discarded and the sediments deposited at the bottom of the test tube subjected to the acetolysis method (Erdtman, 1960). After the acetolysis process, the pollen grains at the bottom of the test tube were collected by means of a glycerin gelatin cube and then sealed with paraffin.

Pollen grains were analyzed qualitatively and quantitatively. Quantitative analysis was performed by counting pollen grains per sample, determining percentages, and defining the following frequency classes: dominant pollen $(>45 \%)$, accessory pollen (15-44\%), important isolated pollen (3-14\%), and isolated or occasional pollen $(<3 \%)$ (Maurizio \& Louveaux, 1965; Barth, 1989). To classify plants into polyniferous or nectariferous, searches were carried out in bibliographies and specialized sites.

In the qualitative analysis, the pollen types in the honeys were determined through comparison with reference slides made from flower buds of plant species collected in the study area, with the help of specialized literature and consultations with specialists. Slides of pollen were made and deposited in the reference palynotheca of the Bee Studies Laboratory, and the exsiccates filed in the MAR Herbarium of the Universidade Federal do Maranhão - UFMA. The APG IV (2016) classification system was adopted and the revision and updating of the names of the taxa were carried out using the electronic database made available by Flora do Brasil 2020 (2019).

For the elaboration of the similarity dendrogram (Bray Curtis index), data related to the months of collection were used, using the Software Past, version 2.17c (Hammer et al., 2001) was used in order to verify the similarity of the samples of honeys from the colonies in the different periods.

\section{RESULTS}

From pollen analyzes of Melipona subnitida honey, 54 pollen types were identified (Figure 3 and Table 1), distributed in 38 genera and 26 families. The largest variety of pollen was found in the families Fabaceae (15\%), Myrtaceae, Amaranthaceae, Arecaceae, and Rubiaceae (5\%, each), and Poaceae, Plantaginaceae, and Polygonaceae (4\%, each). The other families were represented by one single type. Of the 54 pollen types found, 23 are from nectariferous plants (Table 1).

We found that only $4 \%$ of pollen types are dominant pollens, $9 \%$ accessory pollens, and $87 \%$ isolated pollens. The pollen types considered isolated were quite frequent in the samples, with $15 \%$ important isolated pollens (PIi) and $85 \%$ occasional isolated pollens (PIo). Anemophilous pollen was found in honey samples in March, April, and May 2018, which were recorded as occasional isolated pollen (PIo). 
$\mathbf{A}$
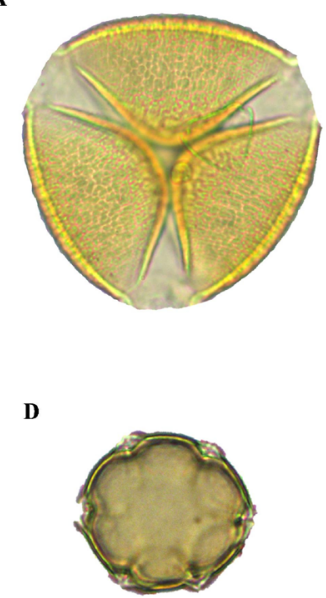

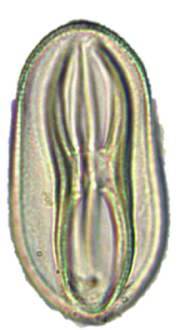

E

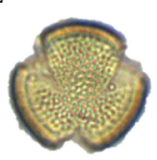

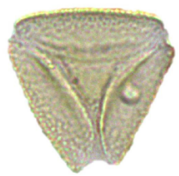

$\mathbf{F}$

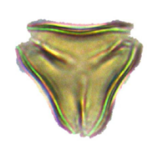

$\mathbf{J}$

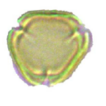

Figure 3. Photomicrographs of pollen types of the most frequent species, foundin honey samples from Melipona subnitida on Ilha Grande do Paulino, Tutóia-MA. A- Neptunia plena (L.) Benth., B- Tipo Chamaecrista, C- Nymphoides humboldtiana (Kunh) Kuntze, D- Manilkara sp., E- Avicennia germinans (L.) L., F- Copaifera martii Hayne var. martii, G- Myrcia multiflora (L.) DC., H- Tipo Borreria, I- Ouratea fieldingiana (Gardner) Engl., J- Rhizophora mangle L. Scale bar $=10 \mu \mathrm{m}$.

Pollen from Copaifera martii, considered as polyniferous and nectariferous, was dominant in December 2017 and January 2018, and classified as accessory pollen in the months of February, March, and April 2018. Myrcia multiflora, which is only polyniferous, presented dominant pollen in the months of August and November 2017 and accessory in September and October 2017; and in the months of January, February, March, May, and June 2018. These two species were observed over the 12 months in the honey samples.

Quantitative analyzes of pollen grains in the honey samples shower that three of the samples were monofloral, that of July with Avicennia germinans honey and that of December and January with Copaifera martii honey. In the other months, the samples demonstrated heterofloral honeys.

Pollens from only two mangrove species, Avicennia germinans and Rhizophora mangle, were found in the honey samples, while all the other pollens were from plants in the restinga area.

Pollen types of species of exotic plants with available nectar located very close to the meliponary, such as Psidium sp. and Syzygium sp., were not found in honey samples, demonstrating the preference of bees for native species or the region. However, the native species Anacardium occidentale ("caju"), despite being quite common on the island, was not observed in honey samples. The pollens of Nymphoides humboldtiana and Neptunia plenum, common species of wetlands and observed close to the meliponary, were detected at low frequency.

Due to the great difficulty in determining some pollen types, it was decided to include species with the same or similar pollen grains. This occurred with six pollen types, in the case of the Borreria type, there may be species of Borreria verticilata and Mitracarpus strigosus, and for the Chamaecrista type there may be C. calycioides, C. diphylla, C. flexuosa, and/or C. ramosa.

In the similarity dendrogram, the honey samples formed two groups (Figure 4). The December/2017-June/2018 samples were grouped with $40 \%$ similarity. The July/2017-November/2017 samples presented $35 \%$ similarity. In the first group, the months of December/2017 and January/2018 demonstrated $81.25 \%$ similarity between the species (Copaifera martii, and Myrcia multiflora). In group two, the months of August and October 2017 presented $81.41 \%$ similarity (Avicennia germinans, and Myrcia multiflora) (Table 1). 


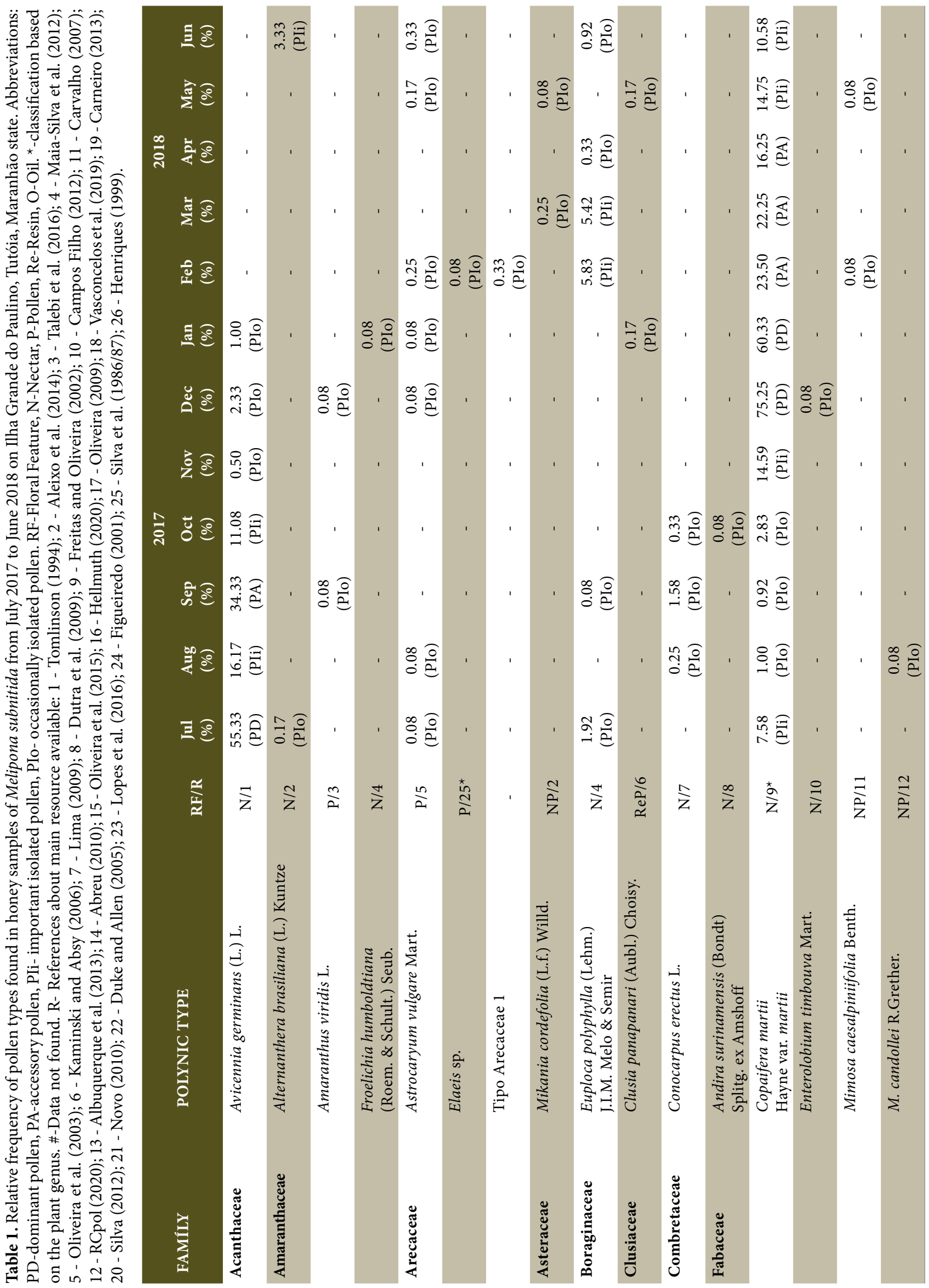




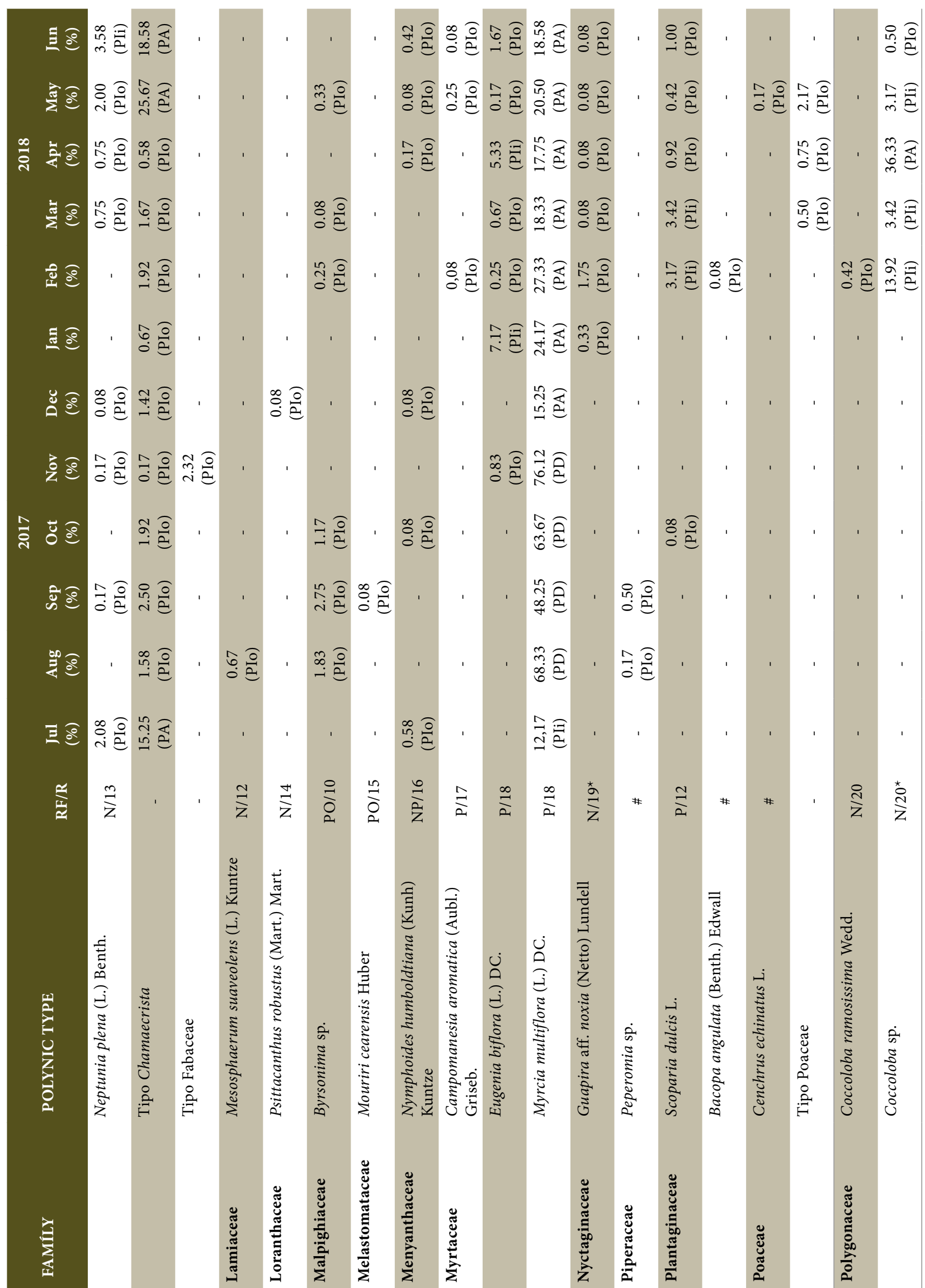




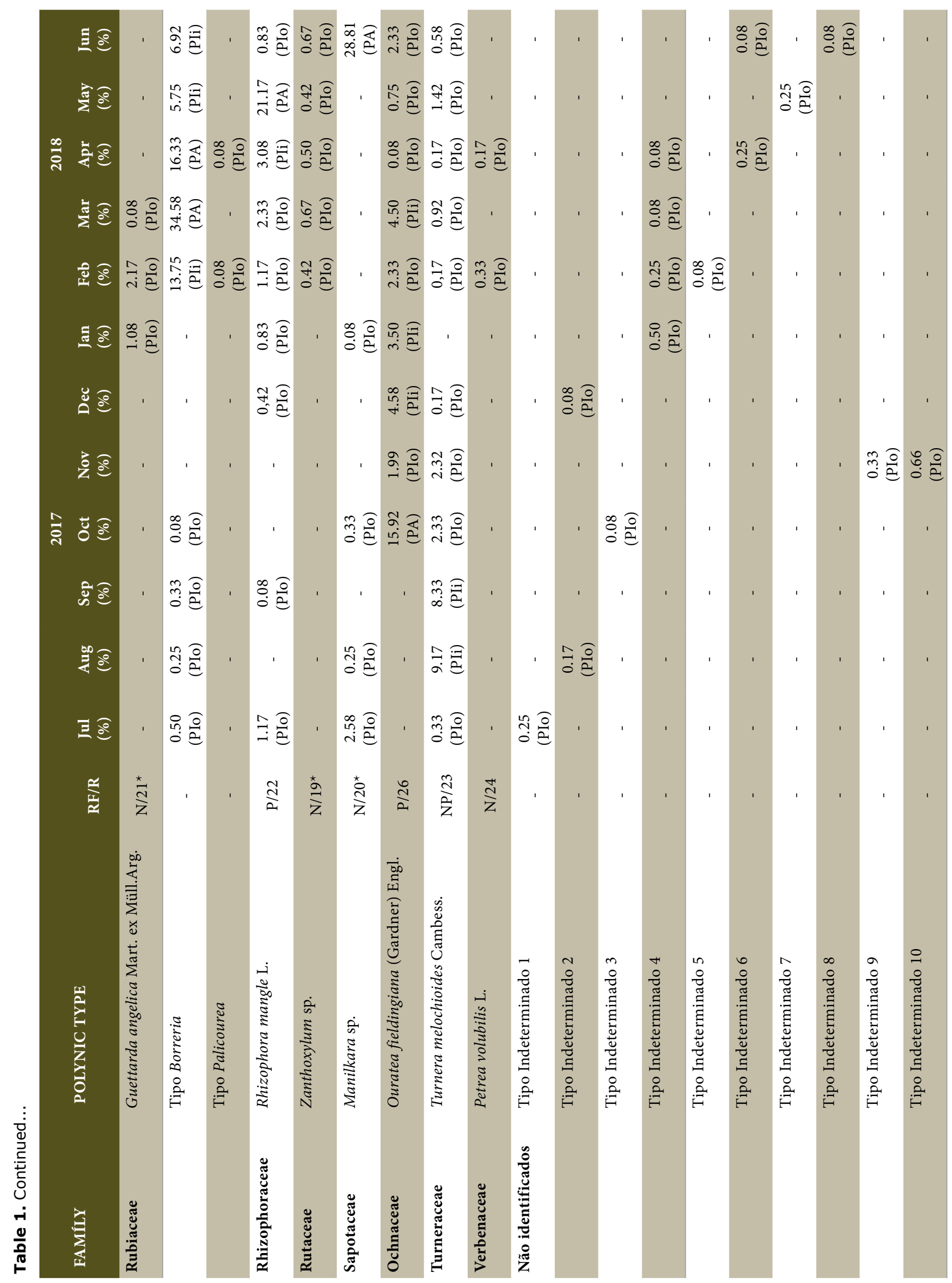




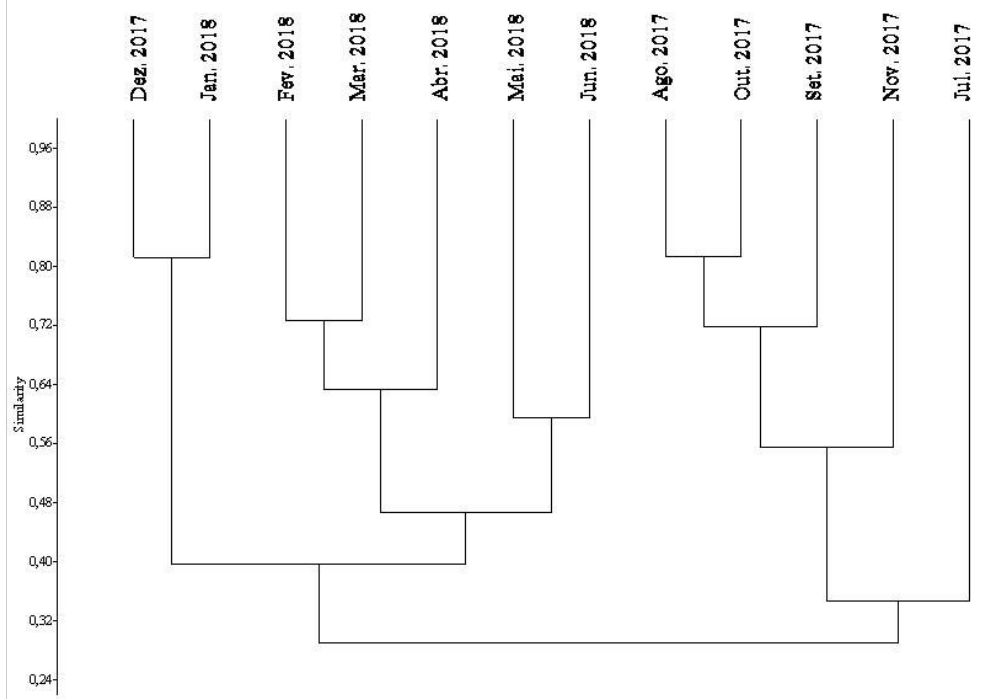

Figure 4. Similarity dendrogram of honey samples from the Melipona subnitida colonies from July 2017 to June 2018 in Ilha Grande do Paulino, Tutóia, Maranhão state.

\section{DISCUSSION}

Analyzes showed that Melipona subnitida uses a wide variety of plants to obtain its food (nectar and pollen), being considered a polyletic bee (Roubik, 1989), in different studies carried out in Brazil (Absy et al., 1980-Manaus; Kerr et al., 1986; Martins et al., 2011-Maranhão; Carvalho et al., 2001; Alves et al., 2006-Bahia; Radaeski et al., 2019-Rio Grande do Sul).

Pinto et al. (2014) and Costa et al. (2017) observed that Melipona subnitida uses a great diversity of flowers to acquire its food, although with differences in the species found. This variation in plants between regions can often be explained by the diversity and characteristics of the local flora, edaphoclimatic conditions, distance from colonies to available resources, and level of degradation of local vegetation (Carvalho et al., 2001).

The greatest pollen richness was found among Fabaceae, Myrtaceae, Amaranthaceae, Arecaceae, Rubiaceae, Poaceae, Plantaginaceae, and Polygonaceae. The Fabaceae, and Myrtaceae families are important in the diet of stingless bees (Ramalho et al., 1990). According to Souza et al. (2015), species of Fabaceae, mainly from the subfamily Mimosoideae, offer an abundance of nectar and pollen resources for bees. Some species of the Myrtaceae family, on the other hand, attract bees through the sweet scent exhaled by flowers, offering pollen to their visitors (Oliveira et al., 2009).

Pollens classified as isolated presented a high percentage (87\%), and similar indices were found in other studies (Alves et al., 2006; Martins et al., 2011; Sousa et al., 2015). Pollen grains classified as Isolated Pollens are of little importance in terms of the amount of nectar supplied, however, they can provide data on the geographical origin of the sample (Barth, 1989). Pollen grains classified as occasional isolated pollen, which obtained $85 \%$, are characteristic of Brazilian honeys according to Barth (1970).

The species Mimosa caesalpiniifolia and Mimosa candolei were recorded as Occasional Isolated Pollens (PIo). Species of this genus are suppliers of little nectar, but a lot of pollen (Barth, 1989). However, Carvalho (2007) considers that M. caesalpiniifolia is a plant that produces a large amount of pollen, and also an abundance of nectar, being classified for a long time as a polyniferous plant, not being included how nectariferous plants.

In several melissopalynology studies, species of the genus Mimosa appear in the pollen spectrum in almost every month of the year, and in some of them as dominant pollen (Alves et al., 2006; Oliveira et al., 2010; Martins et al., 2011; Costa et al., 2017). Perhaps some of the reasons for the low representativeness of Mimosa in honey samples on Ilha Grande do Paulino are related to the fact that one species (Mimosa caesalpiniifolia) does not occur close to the meliponary and these species have a short flowering period, only recorded in March. In general, the flowering of this species extends from April to June (Ribaski, 2003), while in Bahia the flowering peak occurs from April to May (Dohler \& Pina, 2017).

Pinto et al. (2014) in a restinga area and with the bee M. subnitida, also found a low percentage of pollen $(<3 \%)$ for Mimosa caesalpiniifolia, over four months (April, June, August, and October). 
Another pollen considered Occasional Isolated Pollen was from anemophilous plants, such as species of Poaceae. These plants do not produce nectar, only large amounts of pollen that serve as proteins for bees (Barth, 2004; 2005).

Plants of the genus Copaifera produce nectar and pollen, with pollen being present in greater quantities than nectar (Rigamonte-Azevedo et al., 2004). A study carried out with Copaifera langsdorffi i showed that the species only produces about $0.2 \mu \mathrm{l}$ of nectar (Freitas \& Oliveira, 2002). Although plants of this genus do not provide a large amount of nectar and, therefore, do not contribute to the production of honey, being considered important sources of proteins for maintaining colonies (Almeida-Anacleto et al., 2012; Pinto et al., 2014).

In several studies on honey analysis, large amounts of pollen from polliniferous plants are found, mainly from Myrtaceae (Martins et al., 2011; Pinto et al., 2014; Luz et al., 2019). The high representation of pollinating plants may be related to contamination (Barth 1989), between the bees forage with the nectar-receiving worker bees during the exchange of food, or it is due to the fact that the bees deposit the pollen grains collected in the honey pots (Costa et al. 2017).

The pollinating species Myrcia multiflora and the Chamaecrista type are important sources of food for bees, because the pollen types of these species appeared in the 12 months evaluated. Avicennia germinans despite occurring only in seven months, it also has great importance for bees in view of the large amount of nectar (Raju et al. 2012). Thus, the present study shows the need to conserve the species found in the pollen spectrum as they are important sources of resources for bees.

Analyzing the results of studies carried out with bees of the genus Melipona, it was observed that honeys are also heterofloral (Carvalho et al., 2001; Alves et al., 2006; Martins et al., 2011; Silva, 2016; Costa et al., 2017); being common in stingless bees (Souza et al., 2006).

Balata (2008), analyzing the honey of the stinging bee (Apis mellifera) in a mangrove area, observed that some plant species in this ecosystem contribute to the production of honey, with a high percentage of pollen from Laguncularia racemosa $(47 \%)$. During the dry period, some apiarists in the state of Maranhão migrate their hives to the mangrove area, where they remain until the beginning of the rainy season, in order to increase honey production (Balata, 2008). This is because the mangrove species show annual variation in flowering and flower peaks from August to January (Fernandes, 1999).

Other plants that provide nectar for honey production are exotic plants. In Bahia, Carvalho et al. (2001) found dominant pollen from species of Eucalyptus spp. and Psidium sp. in honey of Melipona scutellaris Latreille. In Ceará, Aires \& Freitas (2001) with the bee Apis mellifera L. found pollen of Aloysia virgate (Ruiz \& Pav.) Juss., Cocos nucifera L., and Eucalyptus sp. that showed great potential for honey production.

The native species Anacardium occidentale is one of the main plants pollinated by stingless bees in search of nectar, mainly by Melipona subnitida (Maia-Silva et al., 2012), however, from the analyzes, the presence of pollen of this species was not observed in honey. Although the species is considered by the authors mentioned above as a plant pollinated by Melipona subnitida, Silva et al. (2014) pointed out that the cashew tree is not a good source of pollen or nectar, as bees visit it only because it blooms in the dry period.

In the analysis of tiúba honey (Melipona fasciculata Smith) performed by Martins et al. (2011), the species Pontederia parviflora, found in flooded areas of the Baixada Maranhense, was important for the production of honey. This plant offers nectar as the main resource and occurred as a dominant pollen in five months and an accessory in three months. Neptunia plena and Nymphoides humboldtiana, which demonstrate nectar availability and occur in flooded areas close to the study meliponary, presented isolated pollens.

In the analysis of similarity between the honey samples, two large groups were formed: Group 1 (December 2017 to June 2018) and Group 2 (July 2017 to November 2017). This may be related to rainfall in the region, with the dry period between July and December being recorded, and the rainy period from January to June (Oliveira \& Frota, 2011). In Group 1 (rainy season) the largest number of pollen types was found, due to the greater number of species in flowering, providing a greater supply of food resources for bees (Moraes et al., 2020). The similarity between the December/2017 and January/2018 samples; August/2017 and October/2017 have in common the abundance of pollen grains from Copaifera martii and Myrcia multiflora; Avicennia germinans and Myrcia multiflora, respectively.

\section{CONCLUSIONS}

Based on the study carried out, 54 pollen types were identified confirming that Melipona subnitida is quite generalist in food collection, visiting several species in the restinga. The pollen profile of honey from the island of "Ilha do Paulino" is mainly made up of representatives of the family Fabaceae, Myrtaceae, Amaranthaceae, Arecaceae, Rubiaceae, Poaceae, Plantaginaceae, and Polygonaceae. In the analyzed samples, a large amount of isolated pollens was registered, demonstrating that the bees had no preference for any flowering. In the months of December 2017 and January and July 2018, honey was registered as monofloral. This can be explained by the preference of bees for flowering Avicennia germinans and Copaifera martii. 
In all honey samples collected throughout the year, pollens of Fabaceae (Copaifera martii, Chamaecrista type) and Myrtaceae (Myrcia multiflora) were observed in their composition, showing the great meliponic potential of these plants in the region. Finally, knowing the plants visited by bees are important for meliponicultores to understand the relationship between meliponicola flora and their colonies, being able to invest in the colonies and consequently add more commercial value to the type of honey produced.

\section{ACKNOWLEDGEMENTS}

To the Coordination for the Improvement of Higher Education Personnel - CAPES (finance code 001) for granting the doctoral scholarship granted to the first author. The Foundation for the Support of Research and Scientific and Technological Development of Maranhão (FAPEMA) for financing the project and the penultimate author's productivity grant. And the family of Mr. Francisco and Mrs. Conceição, from Ilha Grande do Paulino, who gave us all logistical support for collections.

\section{SUBMISSION STATUS}

Received: 05 Aug. 2020

Accepted: 14 Dec. 2020

Associate editor: Rodrigo Studart Corrêa:

\section{CORRESPONDENCE TO Maira Rodrigues Diniz}

Universidade Federal do Maranhão, Programa de Pós-Graduação em Biodiversidade e Biotecnologia da Rede BIONORTE, Av. dos Portugueses, 1966, CEP 65080-805, São Luís, MA, Brasil. e-mail: maira_rodrigues@yahoo.com.br

\section{REFERENCES}

Abreu GTJ. História natural da erva-de-passarinho Psittacanthus robustus (Loranthaceae) em uma área de campo rupestre do sudeste brasileiro $=$ interações com hospedeiras, dispersores, polinizadores e insetos herbívoros. [Tese] Universidade Estadual de Campinas. Instituto de Biologia; 2010.

Absy ML, Bezerra EB, Kerr WE. Plantas nectaríferas utilizadas por duas espécies de Melipona da Amazônia. Acta Amazonica 1980; 10(2): 271-281. 10.1590/1809-43921980102271

Aires ERB, Freitas BM. Caracterização palinológica de algumas amostras de mel do estado do Ceará. Ciência agronômica 2001; 32(1/2): 22-29.

Albuquerque PMC, Gostinksi LF, Rêgo MMC, Carreira LMM. Flores abelhas: a interação da tiúba (Melipona fasciculata, Meliponini) com suas fontes florais na Baixada Maranhenses. São Luis; 2013.

Aleixo KP, Faria LB, Groppo M, Castro, MMN, Silva, CI. Spatiotemporal distribution of floral resources in a Brasilian city: implications for the maintenance of pollinators, especially bees.
Urban Forestry \& Urban Greening 2014; 13: 689-696. //doi.org/ 10.1016/j.ufug.2014.08.002

Almeida-Anacleto D, Marchini LC, Camargo AC, Moreti C, Souza V. Plants used by bees as pollen sources in the Brazilian "Cerrado". Sociobiology 2012; 59(4): 1483-1493. 10.13102/sociobiology. v59i4.521

Alves RMO, Carvalho CAL, Souza BA. Espectro polínico de amostras de mel de Melipona mandacaia Smith, 1863 (Hymenoptera: Apidae). Acta Scientiarum. Biological Sciences 2006; 28(1): 65-70. 10.4025/ actascibiolsci.v28i1.1061

APG. An update of the angiosperm phylogeny group classification for the orders and families of flowering plants: APG IV. Botanical Journal of the Linnean Society 2016; 181:1-20. 10.1111/boj.12385

Balata RA. Caracterização da criação de abelhas africanizadas (Apis mellifera L.) em um ecossistema de mangue-Campo de PerizesMA. [Dissertação]. São Luís: Universidade Estadual do Maranhão; 2008.

Barth OM. Microscopic analysis of some samples of honey. 3. Isolated pollen. Anais da Academia Brasileira de Ciências 1970; 42: 747-772.

Barth OM. O Pólen no Mel Brasileiro. Rio de Janeiro: Luxor; 1989.

Barth OM. Melissopalynology in Brazil: a review of pollen analysis of honeys, propolis and pollen loads of bees. Scientia Agrícola 2004; 61(3): 342-350.

Barth OM. Análise polínica de mel: avaliação de dados e seu significado. Revista Mensagem Doce 2005; 81(3): 02-06. 10.1590/ S0103-90162004000300018

Camargo JF, Pedro SRM. Meliponini Lepeletier, 1836. In: Moure JS, Urban D, Melo GR, editores. Catalogue of bees (Hymenoptera, Apoidea) in the Neotropical region. Curitiba: Sociedade Brasileira de Entomologia; 2007.

Campos Filho EM. Plante as árvores do Xingu e Araguaia. São Paulo: Instituto Socioambiental; 2012.

Caravela M, Vilas-Boas M, Russo-Almeida P, Silveira P. Inventário da flora melífera e caracterização palinológica e físico-química do mel da Quinta Ecológica da Moita. Captar 2019; 8(1): 61-75. 10.34624/captar.v8i1.3801

Carvalho CAL, Moreti ACCC, Marchini LC, Alves RMO, Oliveira PCF. Pollen spectrum of honey of "uruçu" bee (Melipona scutellaris Latreille, 1811), Revista Brasileira de Biologia 2001; 61(1): 63-67. 10.1590/S0034-71082001000100009

Carneiro MS. Efeito da estrutura da paisagem sobre a riqueza e diversidade de árvores em grupos funcionais reprodutivos. [Dissertação] Universidade Federal de Alfenas; 2013.

Carvalho PER. 2007. Sabiá - Mimosa caesalpiniifolia. Colombo: Embrapa Floresta, 10p. (Embrapa Floresta. Circular Técnica, 135).

Carvalho, GCA. Flora de importância polínica utilizada por Melipona (Melikerria) fasciculata Smith, 1854 (Hymenoptera: Apidae: meliponini) em uma área de floresta amazônica na região da baixada maranhense, Brasil. Oecologia Australis 2016; 20(1): 58-68.

Costa CCA, Silva CI, Maia-Silva C, Limão AAC, Imperatriz-Fonseca VL. Origem botânica do mel da Jandaíra em áreas de Caatinga nativa do Rio Grande do Norte. In: Imperatriz-Fonseca VL, Koedam D, Hrncir M, editores. A abelha jandaíra no passado, no presente e no futuro. Mossoró: EdUFERSA. 2017. 
Cruz DO, Freitas BM, Silva LA, Silva SEM, Bomfim IGA. Adaptação e comportamento de pastejo da abelha jandaíra (Melipona subnitida Ducke) em ambiente protegido. Acta Scientiarum Animal Sciences 2004; 26(3): 293-298. 10.4025/actascianimsci.v26i3.1777

Dutra VF, Vieira MF, Garcia FCP, Lima HC. Fenologia reprodutiva, síndromes de polinização e dispersão em espécies de leguminosae dos campos rupestres do parque estadual do Itacolomi, Minas Gerais, Brasil. Rodriguésia 2009; 60 (2): 371-387. https://doi.org/ $10.1590 / 2175-7860200960210$

Döhler TL, Pina WC. Abelhas (Hymenoptera: Apoidea) visitantes florais do sabiá (Mimosa Caesalpiniifolia Benth.) em Teixeira de Freitas, Bahia, Brasil. Scientia Plena 2017; 13(8): 1-7. 10.14808/ sci.plena.2017.088001

Duke NC, Allen JA. Rhizophora mangle, R. samoensis, R. racemosa, $R . \times$ harrisonii (Atlantic-East Pacific red mangroves). [2005]. Available from: file://C:/Users/maira/Downloads/ 2006_DukeAllenRh-AEP.pdf

Erdtman G. The acetolysis method. A revised description. Svensk Botanisk Tidskrift 1960; 54: 561-564.

Fernandes MEB. Phenological patterns of Rhizophora L., Avicennia L. and Laguncularia Gaertn. f. in Amazonian mangrove swamps. Hydrobiologia 1999; 413: 53-62. 10.1023/A:1003866108086

Figueiredo LFA. Plantas que atraem aves. 2 ed São Paulo: Centro de Estudos Ornitológicos; 2001.

Flora do Brasil 2020 em construção. 2019. Flora do Brasil 2020. Jardim Botânico do Rio de Janeiro. http://floradobrasil.jbrj.gov.br/. 04 de Outubro de 2019.

Freitas CV, Oliveira PE. Biologia reprodutiva de Copaifera langsdorffi Desf. (Leguminosae, Caesalpinioideae). Revista Brasileira Botânica 2002; 25(3): 311-321. 10.1590/S0100-84042002000300007

Hammer $\varnothing$, Harper DAT, Ryan PD. PAST: Paleontological Statistics Software Package for Education and Data Analysis. Palaeontologia Electronica 2001; 4: 1-9.

Hellmuth N. Floating Heart Water Snowflake. FLAAR mesoamerica; 2020.

Henriques RPB. Ecologia da polinização de Ouratea hexasperma (st. Hil.) Bail (Ochnaceae) em cerrado no Brasil central. Boletim do Herbário Ezechias Paulo Heringer 1999; 4: 46-64.

Kaminski AC, Absy ML. Bees visitors of three species of Clusia (Clusiaceae) flowers in Central Amazonia. Acta Amazonica 2006; 36(2): 259-264.

Kerr WE, Absy ML, Souza ACM. Espécies nectaríferas e poliníferas utilizadas pela abelha Melipona compressipes fasciculata (Meliponinae, Apidae), no Maranhão. Acta Amazonica 1986; 16: 145-156. 10.1590/1809-43921986161156

Köppen W, Geiger R. Klimate der Erde. Gotha: Verlag Justus Perthes; 1928

Lima NTC. Fenologia, ecologia da polinização e reprodução de espécies de manguezal, no município de Goiana-PE. [Tese], Universidade Federal de Pernambuco; 2009.

Luz CFP, Barth, OM. Pollen analysis of honey and beebread derived from Brazilian mangroves. Brazilian Journal of Botany 2012; 35(1): 79-85. 10.1590/S0100-84042012000100009
Luz CFP, Fidalgo ADO, Silva SAY, Rodrigues SDS, Nocelli RCF. Comparative floral preferences in nectar and pollen foraging by Scaptotrigona postica (Latreille 1807) in two different biomes in São Paulo (Brazil). Grana 2019; 58: 200-226. 10.1080/00173134.2019.1579257

Lopes CGR, Beirão DCC, Pereira LA, Alencar LC. Levantamento da flora apícola em área de cerrado no município de Floriano, Estado do Piauí, Brasil. Revista Brasileira Biociências 2016; 14 (2): 102-110.

Louveaux J, Maurizio A, Vorwohl G. Methodik der melissopalynologie. Apidologie 1970; 1(2): 193-209. 10.1051/apido:19700205

Maia-Silva C, Silva CI, Hrncir M, Queiroz RT, Imperatriz-Fonseca VL. Guia de plantas: visitadas por abelhas na caatinga. 2 ed. Fortaleza: Editora Fundação Brasil Cidadão; 2012.

Maia-Silva C, Hrncir M, Silva CI, Imperatriz-Fonseca V.L. Survival strategies of stingless bees (Melipona subnitida) in an unpredictable environment, the Brazilian tropical dry forest. Apidologie 2015; 46: 631-643. 10.1007/s13592-015-0354-1

Martins ACL, Rêgo MMC, Carreira LMM, Albuquerque PMC. Espectro polínico de mel de tiúba (Melipona fasciculata Smith, 1854, Hymenoptera, Apidae). Acta Amazonica 2011; 41(2): 183-190. 10.1590/S0044-59672011000200001

Maurizio A, Louveaux J. Pollen de plantes melíferas d'Europe. Paris: U.G.A.F.; 1965.

Michener CD. The bees of the world. 2 ed. Baltimore: The Johns Hopkins University Press; 2007.

Moraes JIS, Lopes MTR, Ferreira-Gomes RL, Lopes ACA, Pereira FM, Souza BA, Pereira LA. Bee Flora and Use of Resources by Africanized Bees Floresta \& Ambiente 2020; 27(3): 2-9. 10.1590/2179-8087.008317

Novo RR. Biologia reprodutiva de Guettarda platypoda DC. (Rubiaceae) em uma área de restinga no estado de Pernambuco. [Dissertação] Recife: Universidade Federal Rural de Pernambuco. 2010.

Oliveira MIU. O gênero Campomanesia Ruiz \& Pavón (My.rtaceae) para o estado da Bahia. [Dessertação], Universidade Estadual de Feira de Santana; 2009.

Oliveira FPM, Absy ML, Miranda IS. Recurso polínico coletado por abelhas sem ferrão (Apidae, Meliponinae) em um fragmento de floresta na região de Manaus - Amazonas. Acta Amazonica 2009; 39(3): 505-518. 10.1590/S0044-59672009000300004

Oliveira PP, Van Den Berg C, Santos FAR. Pollen analysis of honeys from Caatinga vegetation of the state of Bahia, Brazil. Grana 2010; 49(1): 66-75. 10.1080/00173130903485122

Oliveira MSP, Couturier G, Beserra P. Biologia da polinização da palmeira tucumã (Astrocaryum vulgare Mart.) em Belém, Pará, Brasil, Acta Botanica Brasilica 2003; 17(3): 343-353. //doi.org/ 10.1590/S0102-33062003000300002

Oliveira WR, Frota PV. Caracterização socioambiental do município de Tutóia - Maranhão. Revista Geográfica de América Central 2011; 2(47E): 1-15.

Rego MMC, Albuquerque PMC, Santos FO. Criuli: fonte valiosa de pólen e óleo floral. Ciência Hoje 2010; 47 (277): 66-68.

Pinto RS, Albuquerque PMC, Rêgo MMC. Pollen Analysis of Food Pots Stored by Melipona subnitida Ducke (Hymenoptera: Apidae) in a Restinga area. Sociobiology 2014; 61(4): 461-469. 10.13102/ sociobiology.v61i4.461-469 
Prompt CH. 2010. Capacitação em Bioconstrução na Ilha Grande do Paulino. file://C:/Users/Usuario/Downloads/Capacitacao\%20em\% 20Bioconstrucao\%20na\%20Ilha\%20Grande\%20do\%20Paulino.pdf. 01 de Maio de 2018.

Radaeski JN, Silva CI, Bauermann SG. Melissopalinologia no Rio Grande do Sul: revisão e caracterização das espécies botânicas potenciais à apicultura e meliponicultura. Acta Biológica Catarinense 2019; 6(2): 63-75. org/10.21726/abc.v6i2.698

Raju AJS, Rao PVS, Kumar R, Mohan SR. Biologia da polinização das espécies cripto-vivíparas Avicennia (Avicenniaceae). Journal of Threatened Taxa 2012; 4 (15): 3377-3389. doi.10.11609/ JoTT.o2919.3377-89

Ramalho M, Kleinert-Giovannini A, Imperatriz-Fonseca VL. Important bee plants for stinglesss bees (Melipona and Trigonini) and Africanized honeybees (Apis mellifera) in tropical habitats: a Review. Apidologie 1990; 21(5): 469-488.

Rede de catálogos polínicos online. Disponível em: <http://chaves. rcpol.org.br/>. 04 de novembro de 2020.

Rêgo MMC, Albuquerque PMC. Redescoberta de Melipona subnitida Ducke (Hymenoptera: Apidae) nas restingas do Parque Nacional dos Lençóis Maranhenses, Barreirinhas, MA. Neotropical Entomology 2006; 35(3): 416-417. 10.1590/S1519-566X2006000300020

Rêgo MMC, Albuquerque PMC, Pinto RS, Barbosa MM, Silva AG. A abelha jandaíra no estado do Maranhão. In: Imperatriz-Fonseca VL, Koedam D, Hrncir M. A abelha jandaíra no passado, no presente e no futuro. Mossoró: EdUFERSA; 2017.

Ribaski J, Lima PCF, Oliveira VR, Drumond MA. Sabiá (Mimosa caesalpiniaefolia) Árvore de Múltiplo uso no Brasil. Colombo: Embrapa Floresta, 10p. (Embrapa Floresta. Circular Técnica, 104). 2003.

Rigamonte-Azevedo OC, Wadt PGS, Wadt LDO. Copaíba: ecologia e produção de óleo-resina. Rio Branco: Embrapa Acre, 28p. (Embrapa Acre. Circular Técnica, 91). 2004.

Roubik DW. 1989. Ecology and natural history of tropical bees. USA, Cambridge University press.

Silva MF, Miranda IPAM, Barbosa EM. Aspectos sobre a polinização do "Dendezeiro" Elaeis guineensis Jacq. E do "Caiauê" Elaeis oleifera (H.B.K) Cortês Arecaceae. Acta Amazônica 1986/87; 16/17: 209-218.
Silva FO da. Biodiversidade e interações positivas em moitas de restinga. [Tese], Bahia: Universidade Federal da Bahia. 2012.

Silva, CI et al. Pollen catalog of plants used in bee's diet in different types of vegetation. In: Cláudia Inês da Silva, Jefferson Nunes Radaeski, Mariana Victorino Nicolosi, Arena Soraia Girardi Bauermann (orgs). Atlas of pollen and plants used by bees. p. 105-248, 2020.

Silva CI, Aleixo KP, Nunes-Silva B, Freitas BM, Imperatriz-Fonseca VL. Guia ilustrado de abelhas polinizadoras no Brasil. São Paulo: USP; 2014.

Silva APC. Perfil palinológico do mel e pólen de Melipona asilvai Moure: uma análise do espectro polínico de amostras coletadas simultaneamente em uma área de caatinga na Bahia, Brasil. [Tese], Feira de Santana: Universidade Estadual de Feira de Santana; 2016.

Souza B, Roubik D, Barth MO, Heard T, Rnríquez E, Carvalho C et al. Composition of Stingless bee Honey: Setting Quality Standards. Interciencia 2006; 31(12): 867-875.

Souza LS, Lucas CIS, Conceição PJ, Paixão JF, Alves RM. Pollen spectrum of the honey of uruçu bee (Melipona scutellaris Latreille, 1811) (Hymenoptera: Apidae) in the North Coast of Bahia State. Acta Scientiarum Biological Sciences 2015; 37(4): 483-489. 10.4025/ actascibiolsci.v37i4.28059

Talebi SM, Noori M, Nasiri Z. Palynological study of some Iranian Amaranthus taxa, Environmental and Experimental Biology 2016; 14: 1-7. 10.22364/eeb.14.01

Tomlinson PB. The botany os mangroves. 2 ed. Cambridge University Press, Cambridge; 1994.

Vasconcelos TNC, Prenner G, Lucas EJ. A Systematic Overview of the Floral Diversity in Myrteae (Myrtaceae). Systematic Botany 2019; 44 (3): 570-591. doi.org/10.1600/036364419X15620113920617

Venturieri GC, Raiol VFO, Pereira CAB. Avaliação da introdução da criação racional de Melipona fasciculata (Apidae: Meliponina), entre os agricultores familiares de Bragança - PA, Brasil. Biota Neotropica 2003; 3(2): 1-7.

Villas-Bôas J. Manual Tecnológico: Mel de Abelhas sem Ferrão. Brasília. Instituto Sociedade População e Natureza (ISPN). 2012. 